\title{
Damage to diving beetles (Dytiscidae) from willow traps in Lipetsk oblast (Russia) and features of Cybister lateralimarginalis and Dytiscus circumcinctus populations in winter
}

\author{
Ущерб Аля плавунцов (Dytiscidae) от использования кошар в \\ Аипеџкой области и особенности попумяџий Cybister \\ lateralimarginalis и Dytiscus circumcinctus в зимний период
}

\author{
Alexander A. Prokin ${ }^{1,2}$, Alexander I. Zemlyanukhin ${ }^{3}$, Dmitry G. Seleznev ${ }^{1}$ \\ А.А. Прокин ${ }^{1,2}$, А.И. Землянухин ${ }^{2}$, А.Г. Селезнев ${ }^{1}$

\footnotetext{
${ }^{1}$ Papanin Institute for Biology of Inland Waters, Russian Academy of Sciences, Borok, Nekouzsky District, Yaroslavl Oblast', 152742 Russia. E-mail: prokina@mail.ru

${ }^{1}$ Институт биологии внутренних вод им. И.Д. Папанина РАН, Борок, Некоузский р-н, Ярославская обл. 152742 Россия.

${ }^{2}$ Cherepovets State University, prosp. Lunacharskogo 5, Cherepovets, Vologda Oblast', 162600 Russia.

2 Череповецкий государственный университет, просп. Луначарского 5, Череповец, Вологодская обл. 162600 Россия.

3 Semenov-Tian-Shansky Lipetsk State Pedagogical University, Lenina street 42, Lipetsk, 398020 Russia. E-mail: zem-valery@mail.ru
} \\ 3 Липецкий государственный педагогический университет им. П.П. Семёнова-Тян-Шанского, ул. Ленина 42, Липецк, 398020 Россия.
}

KEY WORDS: Dytiscidae, Dytiscus, Cybister, overwintering population, sex ratio, femail morphs, damage. КЛЮЧЕВЫЕ СЛОВА: Dytiscidae, Dytiscus, Cybister, зимующие популяции, соотношение полов, морфы самок, ущерб.

ABSTRACT. The amount of damage from the use of willow traps for Dytiscinae in the oxbow lake in Lipetsk Oblast was $400 \mathrm{~g} /$ trap-day. The sex ratio $\left(\sigma^{7} / q\right)$ in the winter was 0.60 for Cybister lateralimarginalis and 1.73 for Dytiscus circumcinctus. The average biomass of $C$. lateralimarginalis females was significantly higher than in males, there were no significant differences for $D$. circumcinctus. The number of reticulate females in comparison with smooth ones was an order larger in the population of C. lateralimarginalis, and only 1.6 times larger in $D$. circumcinctus. Probably, the predominance of reticulate females in the $C$. lateralimarginalis population, in comparison with Dytiscus, is one of the mechanisms that ensure the expansion of the species range to the north.

How to cite this article: Prokin A.A., Zemlyanukhin A.I., Seleznev D. G. 2018. Damage to diving beetles (Dytiscidae) from willow traps in Lipetsk oblast (Russia) and features of Cybister lateralimarginalis and Dytiscus circumcinctus populations in winter // Russian Entomol. J. Vol.27. No.1. P.11-14. doi: 10.15298/rusentj.27.1.02

РЕЗЮМЕ. Величина ущерба от использования кошар для Dytiscinae в пойменном озере в Липецкой области составила 400 г/ловушко-сутки. Соотношение полов $\left(\sigma^{7} / q\right)$ в зимний период было 0.60 для Cybister lateralimarginalis и 1.73 для Dytiscus circumcinctus. Средняя биомасса самок C. lateralimarginalis была достоверно выше, чем у самцов, для D. circumcinctus достоверных различий не выявлено. Число шагренированных самок по сравнению с гладкими было на порядок больше в популяции $C$. lateralimarginalis, и в 1.6 раз превосходило у $D$. circumcinctus. Возможно, большая доля шагренированных самок в популяции $C$. lateralimarginalis, по сравнению с Dytiscus, - одни из механизмов, обеспечивающих расширение ареала вида на север.

\section{Introduction}

Willow traps [Russian "koshura"] standing in iceholes (Fig. 1), are traditionally used in Lipetsk Oblast by fishermen for catching the European weather loach Misgurnus fossils (L.) in late winter in oxbow lakes, when oxygen levels in the water are especially low. Many other animals, such as the American mink Neovison vison (Schreber), midetteranean water shrew Neomys anomalus Cabrera, water scorpions (Nepa cinerea L.) and diving beetles, usually fall into those traps attracted by the available oxygen or food. Fishermen shake out these "unnecessary" animals onto the ice as they collect loach from the traps, dooming still living specimens to death from the cold (Figs 2-4).

Estimation the sex ratio, weight and ratio of the females morphs in the samples from the ice made it possible to study the population characteristics of mass species of Dytiscidae in winter season.

Material and methods

Alexander I. Zemlyanukhin studied the damage done by such traps on 17-21 February 2017 in the oxbow lake 
Treshchevka in the Voronezh River floodplain, Lipetsk Oblast, 52 $16^{\prime} 56^{\prime \prime} \mathrm{N} 39^{\circ} 26^{\prime} 07^{\prime \prime E}$. Three traps on this lake were checked by fishermen twice, on February $19^{\text {th }}$ and $21^{\text {st }}$. Thus, 12 trap-days were studied.

Four species of Dytiscidae have been recorded: $\mathrm{Co}$ lymbetes paykulli Erichson, 1837, Cybister lateralimarginalis (De Geer, 1774), Dytiscus circumcinctus Ahrens, 1811 and $D$. marginalis Linnaeus, 1758. Only Cybister and Dytiscus species were collected and transferred to A. Prokin for studying. Each specimen was weighed on a torsion balance with a precision of $5 \mathrm{mg}$; the sex and the morph of dimorphic females were recorded.

The specimens are deposited in the collection of the first author in Papanin Institute for Biology of Inland Waters, Borok.

Since the biomass data were normally distributed (Shapiro-Wilk test), the average values in each of the groups were compared by two-way t-test. Logistic regression was used for comparing total number in groups and to construct the models of dependence total number in groups from biomass. All statistical analysis was performed using environment for statistical computing R. In the Tables after + the values of SE are given.

The initial data set and $\mathrm{R}$ code can be downloaded here: www.ibiw.ru/upload/staff/267/dytiscidae.zip.
Table 1. Total biomass of Dytiscinae species, mg. Таблица 1. Общая биомасса представителей Dytiscinae, мг.

\begin{tabular}{l|c|c|c}
\hline \multirow{2}{*}{ Dates } & $\begin{array}{c}\text { C. laterali- } \\
\text { marginalis }\end{array}$ & $\begin{array}{c}\text { D. circum- } \\
\text { cinctus }\end{array}$ & $\begin{array}{c}\text { Dytiscus } \\
\text { marginalis }\end{array}$ \\
\hline $17-19.02 .2017$ & 1079595 & 296835 & - \\
\hline $19-21.02 .2017$ & 2172250 & 1219015 & 32125 \\
\hline \multirow{2}{*}{ Total } & 3251845 & 1515850 & 32125 \\
\cline { 2 - 4 } & \multicolumn{3}{|c}{4799820} \\
\hline
\end{tabular}

\section{Results}

A total of 405 specimens were collected near the traps: $67.9 \%$ C. lateralimarginalis, $32.3 \%$ Dytiscus circumcinctus and $0.8 \%$ D. marginalis. The total wet biomass of dead Dytiscinae was about $5 \mathrm{~kg}$ (Table 1), in recalculation to one trap-day, the magnitude of the damage was $399,985 \mathrm{mg}$.

The sex ratio $\sigma^{\top} / q$ was 0.60 in C. lateralimarginalis and 1.73 in $D$. circumcinctus (Table 2). The average biomasses of Cybister lateralimarginalis males $(11,300$ $\mathrm{mg})$ and females $(12,562 \mathrm{mg})$ (Table 2) were significantly different $(t=7.587$, d.f. $=265, \mathrm{p}<0.001)$. The
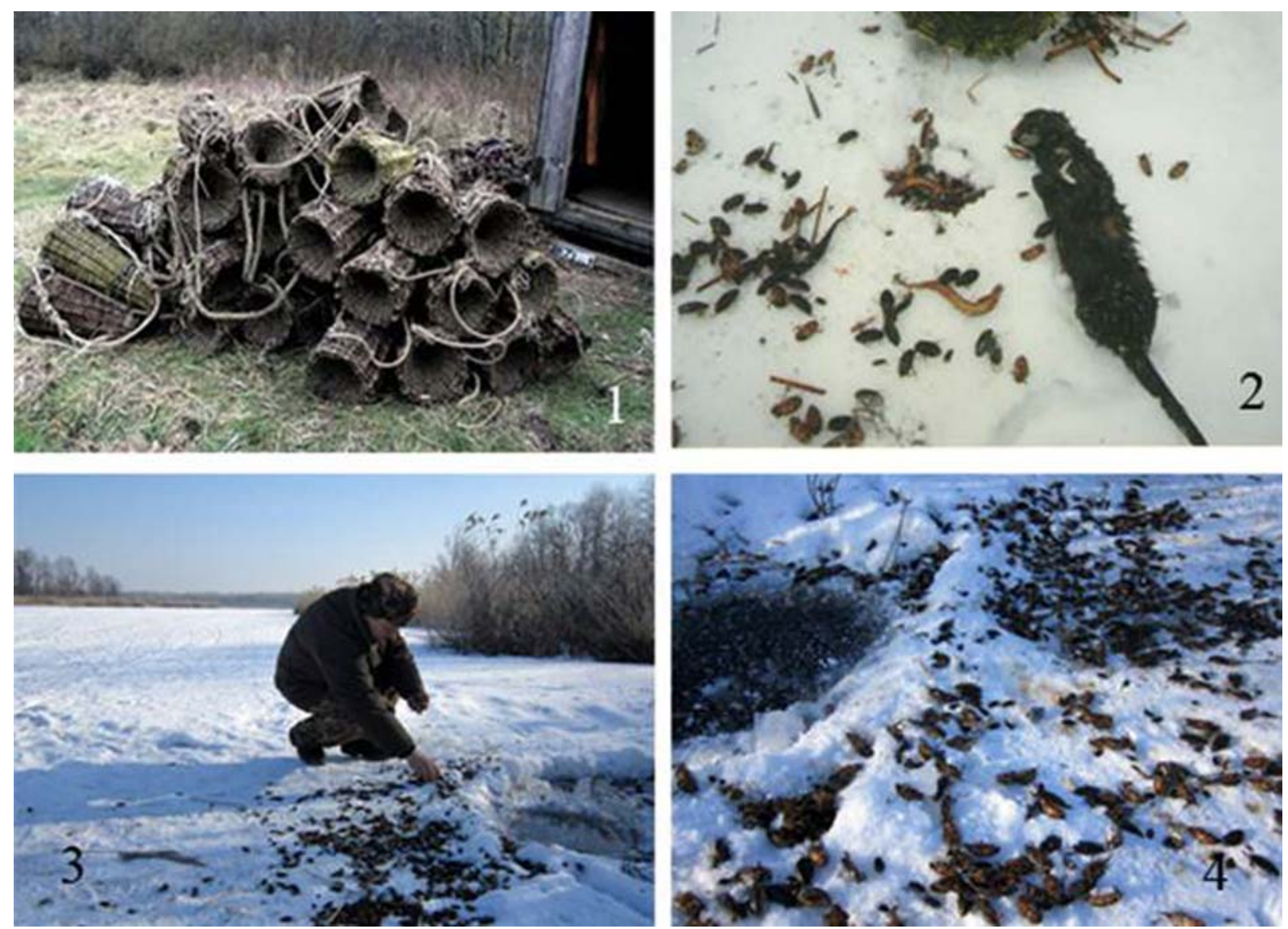

Figs 1-4. 1 - Willow traps or "koshura"; 2 - European weather loaches, American mink and diving beetles shaken out of a willow trap; 3 - A.I. Zemlyanukhin collecting diving beetles from the ice; 4 - diving beetles around the ice-hole.

Рис. 1-4. 1 - кошары; 2 - обыкновенный вьюн, американская норка и плавунцы, выброшенные на лёд из кошары; 3 А.И. Землянухин собирает плавунцов со льда; 4 - плавунцы вокруг лунки. 
Table 2. The number of specimens and biomass $(B)$ of Dytiscinae species sexes. Таблица 2. Число экземпляров и биомасса $(B)$ полов видов Dytiscinae.

\begin{tabular}{l|c|c|c|c|c|c}
\hline \multirow{2}{*}{} & \multicolumn{2}{|c|}{$\begin{array}{c}\text { Cybister } \\
\text { lateralimarginalis }\end{array}$} & \multicolumn{2}{c|}{$\begin{array}{c}\text { Dytiscus } \\
\text { circumcinctus }\end{array}$} & \multicolumn{2}{c}{ Dytiscus marginalis } \\
\cline { 2 - 6 } & $\sigma^{7}$ & $q$ & $\sigma^{7}$ & $q$ & $\sigma^{7}$ & $q$ \\
\hline number, ex. & 102 & 169 & 83 & 48 & 2 & 1 \\
\hline$B$ min, mg & 7040 & 8935 & 9845 & 9235 & 9365 & \\
\cline { 1 - 6 }$B$ max, mg & 13445 & 16960 & 13600 & 13655 & 11795 & \multirow{2}{*}{10965} \\
\cline { 1 - 6 }$B$ average, mg & 11300 & 12563 & 11851 & 11576 & 10580 & \\
& \pm 106 & \pm 128 & \pm 102 & \pm 170 & $\pm 1,215$ & \\
\hline
\end{tabular}

Table 3. Number of specimens and biomass $(B)$ of female morphs of $C$. lateralimarginalis and $D$. circumcinctus. Таблица 3. Число экземпляров и биомасса $(B)$ морф самок $C$. lateralimarginalis и $D$. circumcinctus.

\begin{tabular}{|c|c|c|c|c|}
\hline \multirow{2}{*}{90} & \multicolumn{2}{|c|}{$\begin{array}{c}\text { Cybister laterali- } \\
\text { marginalis }\end{array}$} & \multicolumn{2}{|c|}{$\begin{array}{c}\text { Dytiscus } \\
\text { circumcinctus }\end{array}$} \\
\hline & $\begin{array}{l}\text { reticulate } \\
\text { (striated) }\end{array}$ & smooth & sulcate & smooth \\
\hline number, ex. & 156 & 15 & 30 & 19 \\
\hline$B$ min, mg & 8935 & 9240 & 9235 & 9540 \\
\hline$B \max , \mathrm{mg}$ & 16960 & 14330 & 13655 & 13550 \\
\hline$B$ average, $\mathrm{mg}$ & $\begin{array}{l}12598 \\
\pm 135\end{array}$ & $\begin{array}{l}12370 \\
\pm 358\end{array}$ & $\begin{array}{l}11727 \\
\pm 207\end{array}$ & $\begin{array}{l}11332 \\
\pm 292\end{array}$ \\
\hline
\end{tabular}

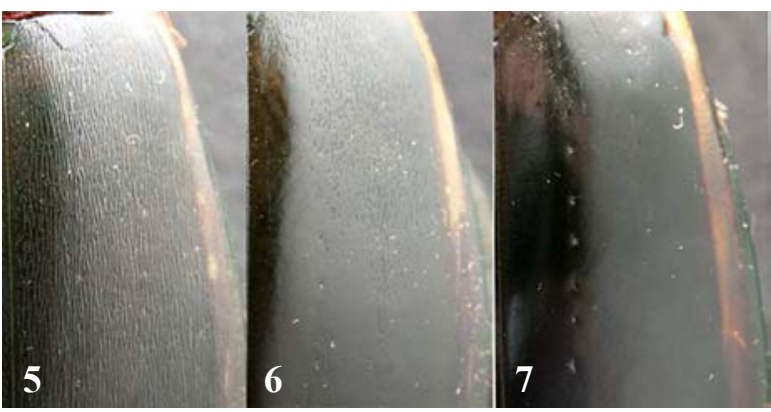

Figs 5-7. Female morphs of Cybister lateralimarginalis: 5 reticulate, 6 - semi-reticulate, 7 - smooth.

Рис. 5-7. Морфы самок Cybister lateralimarginalis: 5 шагренированная, 6 - полу-шагренированная, 7 - гладкая.

average biomasses of Dytiscus circumcinctus males $(11,851 \mathrm{mg})$ and females $(11,576 \mathrm{mg})$ (Table 2) were not significantly different $(t=1.39$, d.f. $=79, \mathrm{p}=0.17)$.

The total number of reticulate (striated) females was about ten times as great as that of smooth ones in $C$. lateralimarginalis, and the number of sulcate females was only 1.6 times as great as that of smooth in $D$. circumcinctus (Table 3, Fig. 8). Thirteen "semi-reticulate" (Figs 5-7) females of C. lateralimarginalis with partly modified elytral surface were recorded and provisionally counted together with the "reticulate" morph.

The average biomass of females with smooth and modified surface of elytra were not significantly different in either species (C. lateralimarginalis, $t=0.59$, d.f. $=13$, $\mathrm{p}=0.56 ; D$. circumcinctus, $t=1.1$, d.f. $=33, \mathrm{p}=0.28$ ).

The numbers of male and female specimens in Cybister lateralimarginalis were different $(z=-4.04$,

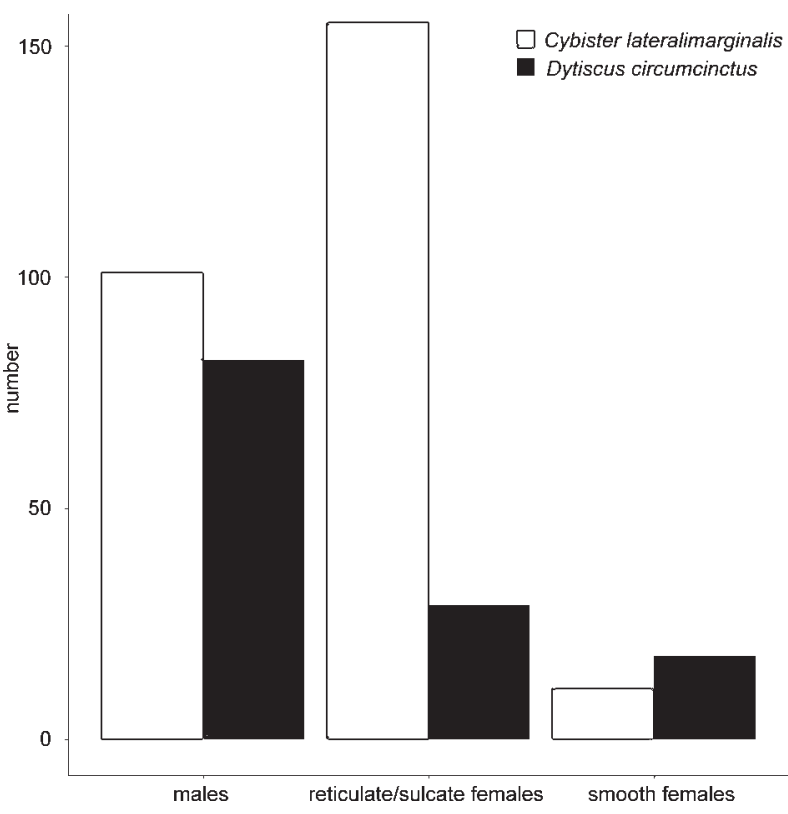

Fig. 8. Number of specimens of males and female morphs in $C$. lateralimarginalis and D. circumcinctus.

Рис. 8. Число экземпляров самцов и морф самок $C$. lateralimarginalis и D. circumcinctus.

$\mathrm{p}<0.001)$ and depended on biomass $(z=-6.15, \mathrm{p}<$ $0.001)$. The numbers of reticulate and smooth females were also different $(z=-8.58, \mathrm{p}<0.001)$, but it did not depend on biomass $(z=-0.97, \mathrm{p}=0.33)$. The numbers of male and female specimens in Dytiscus circumcinctus was different $(\mathrm{z}=3.04, \mathrm{p}=0.002)$ and did not depend on biomass $(z=1.47, \mathrm{p}=0.23)$. The numbers of ribbed and smooth females did not differ significantly $(z=-1.59, \mathrm{p}=0.11)$.

\section{Discussion}

It is well known that female dorsal surface modifications and suction cups of the male fore legs represent a pronounced co-evolutionary pattern with an "arms race" evolutionary trend in diving beetles [Bergsten et al., 2001; Bergsten, Miller, 2007; etc.]. Females with modified dorsal sculpture are more successful than smooth females in dislodging harassing males that can kill the females by hypoxia resulting from multiple mating and 
therefore such females are usually more abundant in natural populations [Bergsten, Miller, 2007].

Therefore, it can be expected that in species with equal biomass of both sexes (such as D. circumcinctus) modified females should be more abundant than those with heavier females (C. lateralimarginalis). However, we observe the exact opposite: modified females occurred five times as often in Cybister as in the Dytiscus. The reason of this pattern is probably associated with the more evolutionarily advanced structure of the male palette in Cybister, in which it is concave and equipped with smaller and more numerous adhesive cups, compared to Dytiscus. This opinion is supported by Nilsson [1986] and Aiken and Khan [1992], who noted that smaller and more numerous discs could be more advantageous for adhesion to a modified (granulate, wrinkled or striated) surface.

The native (primary) range of $C$. lateralimarginalis includes Middle and Southern Europe, North Africa, Western and Central Asia, Mongolia, China, Northern India [Ghosh, Nilsson, 2012; Nilsson, Hájek, 2015]. At present time an expansion of the range of the species to the north are observed.

The most northern record of Cybister lateralimarginalis De Geer, 1774 in Russia is known from the Leningrad Oblast': $60.792^{\circ} \mathrm{N} 30.369^{\circ} \mathrm{E}$ [Litovkin, Sazhnev, 2016]. This record, like the previous ones for the north of the European Russia from Tver and Moscow Oblast's, Chuvashia and Tatarstan [Litovkin, 2012; Petrov, Fedorova, 2013; Petrov et al., 2013] is based on finding adults. The old record for the border area with Finland [Hellen, 1929] is considered doubtful [Kalniò , 1999]. New record based on the finding of larva in Pskov Oblast' [Prokin, Cherevichko, 2017], confirms the naturalization of the species in the north of the European part of Russia.

In Western Europe, the northern border of the range extends across Denmark, southern Sweden and Latvia [Nilsson, Holmen, 1995; Kalniņš, 1999]. Eastwards in Russia the species is known from the Urals in the Chelyabinsk Oblast' [Litovkin, 2012].

Probably, the structure of the overwintering population of Cybister with the predominance of reticulate females, provides this species certain competitive advantages, in comparison with Dytiscus, and therefore make possible to expand a native range to the north.
ACKNOWLEDGEMENTS. This study was supported by the grant of Russian Foundation for Basic Research, project no. 15-04-02971. We are very grateful to Pyotr N. Petrov (Moscow, Russia) and Garth Foster (Ayr, Scotland, UK) for comments on manuscript and language revision of text.

\section{References}

Aiken R.B., Khan A. 1992. The adhesive strength of the palettes of males of a boreal water beetle, Dytiscus alaskanus J. BalfourBrowne (Coleoptera: Dytiscidae) // Canadian Journal of Zoology. Vol.70. P.1321-1324.

Bergsten J., Miller K.B. 2007. Phylogeny of diving beetles reveals a co-evolutionary arms race between the sexes // PLosONE. Vol.2. No.6. e522.doi:10.1371/ journal.pone.0000522.

Bergsten J., Töyrä A., Nilsson A.N. 2001. Intraspecific variation and intersexual correlation in secondary sexual characters of three diving beetles (Coleoptera: Dytiscidae) // Biological Journal of Linnean Society. Vol.73. P.221-232.

Ghosh S.K., Nilsson A.N. 2012. Catalogue of the diving beetles of India and adjacent countries (Coleoptera: Dytiscidae). Skörvnöpparn, Ume. Suppl.3. P.1-77.

Hellen W. 1929. Zur Kenntis einiger Dytisciden Finnlands // Notulae entomologicae. Vol.9. P.34-46.

Kalninš M. 1999. Distribution of the water beetle Cybister lateralimarginalis De Geer, 1774 (Coleoptera, Dytiscidae) in Latvia // Latvijas entomologs. Vol.37. P.38-39.

Litovkin S.V. 2012. [Towards distribution of Cybister lateralimarginalis (De Geer, 1774) (Coleoptera: Dytiscidae) in Russia] // Trudy Orenburgskogo Otdeleniya Russkogo Entomologicheskogo Obshchestva. Vol.2. P.56-58 [in Russian].

Litovkin S.V, Sazhnev A.S. 2016. [New data on the distribution and biology of water beetles (Coleoptera: Haliplidae, Dytiscidae, Helophoridae, Georissidae, Hydrophilidae, Limnichidae, Curculionidae) in Russia] // Euroasian Entomological Journal. Vol.15. No.1. P.17-24 [in Russian, with English summary].

Nilsson A.N. 1986. Geographic variation in Graphoderus zonatus (Coleoptera: Dytiscidae) in Sweden // Entomologica Scandinavica. Vol.17. P.119-125.

Nilsson A.N., Hájek J. 2015. Catalogue of Palearctic Dytiscidae (Coleoptera). Internet version 2015.01.01. http://www2.emg.umu. se/projects/biginst/andersn/Cat_main.htm

Nilsson A.N., Holmen M. 1995. The aquatic Adephaga (Coleoptera) of Fennoskandia and Denmark. II. Fauna Entomologica Scandinavica. Vol.32. 192 pp.

Petrov P., Fedorova D. 2013. Cybister lateralimarginalis in rather northern Russia // Latissimus. No.33. P.7-8.

Petrov P., Khasina M., Eliseev A. 2013. Confirmed presence of Cybister lateralimarginalis and Dytiscus latissimus populations in Tver Oblast (Russia) // Latissimus. No.34. P.19-20.

Prokin A., Cherevichko A. 2017. Naturalisation of Cybister lateralimarginalis in the north of European Russia confirmed by the finding of larva // Latissimus. No.40. P.18-19. 